\title{
FETAL WASTAGE AS A CONSEQUENCE OF MYCOPLASMA PULMONIS INFECTION IN MICE
}

\author{
D. TAYLOR-ROBINSON, C. RASSNER, P. M. FURR, \\ D. P. HUMBER AND R. D. BARNES \\ Clinical Research Centre, Watford Road, \\ Harrow, Middlesex HA1 $3 U \mathcal{J}$
}

(Received 1st Fuly 1974)

\begin{abstract}
Summary. The effect of Mycoplasma pulmonis, strain JB, on the outcome of pregnancy in TO mice was studied. The mice were infected intravenously before or after mating and the fetuses were examined at autopsy just before parturition. An increase in the number of abnormal pregnancies was noted in mice infected about 2 weeks before mating, and there was a significant increase in the number of fetuses which died mid-way through pregnancy. Mycoplasmas were not isolated from any of the fetuses although the organisms reached the joints of the pregnant mice and caused arthritis. It is possible, therefore, that maternal upset was a factor in these abnormal pregnancies. In mice infected at various times after mating, abnormal pregnancies were most frequently seen in those infected 9 days after mating. There was an increase in the number of both mid- and late-stage fetal deaths in these mice and also an increase in the number of late-stage fetal deaths in mice infected 5 days after mating. Mycoplasmas were isolated not only from most of the dead fetuses but also from living ones which suggests that in most instances death was probably due to maternal infection and disturbance rather than fetal infection per se. The possibility of modifying this mouse model by establishing a chronic genital tract infection is discussed as a means of investigating the rôle of mycoplasmas in human abortion.
\end{abstract}

\section{INTRODUCTION}

The isolation of mycoplasmas from the products of human abortion has been recorded by several workers. Mycoplasma hominis was isolated by Jones (1967), Romano, Carollo \& Romano (1968) and Harwick, Purcell, Iuppa \& Fekety (1970), and T-mycoplasmas were recovered by Kundsin, Driscoll \& Ming (1967), Romano, Romano \& Carollo (1971) and Caspi, Solomon \& Sompolinsky (1972). Whether these mycoplasmas, which are commonly found in the female urogenital tract (Taylor-Robinson \& Furr, 1973), are responsible for any human abortions remains uncertain. An increased incidence of abortion has, however, been observed in goats naturally infected by $M$. mycoides var. capri (Cottew, 1970), and Thomas (1970) and Cole, Ward \& Golightly-Rowland (1973) noted that the rat mycoplasma, $M$. arthritidis, caused fetal death when 
injected into pregnant mice. Since, apart from these observations, little is known about the ability of mycoplasmas to cause abortion, infection of mice with a pathogenic strain of $M$. pulmonis was studied in order to determine whether the materno-fetal relationship was affected and, if so, to investigate the mechanisms involved.

\section{MATERIALS AND METHODS}

Mice

Six-week-old outbred TO mice were conventionally housed and isolated in groups of five. Mice of this strain from the same colony were apparently free of endogenous mycoplasma infection. Two experiments were performed, both designed to study the effect of mycoplasma infection on fetal survival. In the first experiment, the results of infection for various periods of time before and during pregnancy were studied and in the second, the results of infection at different stages of pregnancy were examined. In both cases, female mice were inoculated intravenously with $0.2 \mathrm{ml}$ stock $M$. pulmonis culture. In the first experiment, mice were mated at various times up to 15 days after infection. In the second experiment, mice were infected 1, 5 and 9 days after the detection of vaginal plugs. In both experiments, the presence of a vaginal plug was considered to signify successful mating and the day on which it occurred was regarded as Day 1 of pregnancy. Mice were killed on Day 18 or 19 of pregnancy by placing them in an atmosphere of carbon dioxide. They were bled out from the axillary vessels, the spleens and uteri were removed, and living and dead fetuses were counted, dissected out and weighed; in the results, weights are presented \pm 1 S.D. Deaths occurring in the early, middle and late stages of fetal development were assessed according to the criteria of McLaren \& Michie (1959). Statistical analysis of results was based on the $\chi^{2}$ test with Yates' correction for small numbers when applicable.

The presence of arthritis before or during pregnancy was based on the observation of one or more swollen joints.

\section{Mycoplasma}

The JB strain of $M$. pulmonis, known to cause arthritis in mice (Barden \& Tully, 1969), was grown in thallium-free medium described previously (Manchee \& Taylor-Robinson, 1968). This stock culture, stored at $-70^{\circ} \mathrm{C}$, contained $10^{7}$ colour-changing units (c.c.u.) per $0.2 \mathrm{ml}$.

\section{Titration of mycoplasmas}

Each fetus was washed in distilled water, 'snap' frozen in liquid nitrogen and stored at $-70^{\circ} \mathrm{G}$. After thawing at room temperature, the fetal tissue was homogenized in Eagle's medium in a TenBroeck grinder to produce a $10 \%$ $(w / v)$ suspension. Further tenfold dilutions were made in mycoplasma liquid medium contained in screw-capped $2 \cdot 0-\mathrm{ml}$ vials. Homogenized maternal spleen and blood samples, neither of which were stored, were diluted in the same way. Growth of mycoplasmas resulted in a change in colour of the medium from pink to yellow during incubation at $37^{\circ} \mathrm{C}$ (Taylor-Robinson \& Purcell, 
1966). The highest dilution at which a colour change was seen was considered to contain one c.c.u. In the text, mycoplasma titres ( \pm 1 S.D.) are expressed as $\log _{10}$ c.c.u. $/ \mathrm{ml}$.

\section{RESULTS}

\section{Mice infected before mating}

Occurrence of pregnancy. Of the uninfected mice, $90 \%$ became pregnant. The same proportion of mice became pregnant when mated in the first week of infection but only $57 \%$ of mice, which were infected for up to 2 weeks before mating, became pregnant.

Occurrence of abnormal pregnancies. If one or more fetal deaths occurred, a pregnancy was regarded as abnormal. The incidence of abnormal pregnancies in mice infected at different times before mating is shown in Table 1. Pregnancies in which there were fetal deaths at mid-pregnancy were significantly more frequent $(P<0.01)$ in mice that were infected 11 to 15 days before mating than in uninfected mice.

Arthritis in pregnant mice. There was no obvious association of abnormal pregnancy with the occurrence of arthritis, except possibly in mice infected 11 to 15 days before mating. Here, abnormal pregnancies were seen in all five mice that developed arthritis whereas only one abnormal pregnancy occurred in three mice in which arthritis was not observed.

Occurrence of abnormal fetuses. The incidence of fetal death in mice infected for different times before mating is shown in Table 1. The number of fetuses which died in the middle stage of fetal development was greatest in mice infected 11 to 15 days before mating. This number was significantly greater $(P<0.001)$ than the number of dead fetuses which were seen in uninfected mice.

Weights of living fetuses. The mean weights of fetuses removed from mice that were infected 1 to 5 days, 6 to 10 days and 11 to 15 days before mating were $1 \cdot 19 \pm 0 \cdot 14 \mathrm{~g}, 1 \cdot 22 \pm 0 \cdot 16 \mathrm{~g}$ and $1 \cdot 20 \pm 0 \cdot 17 \mathrm{~g}$, respectively.

Isolation of mycoplasmas. Mycoplasmas were isolated from the spleens of all ten mice infected 1 to 5 days before mating (geometric mean titre: $4 \cdot 3 \pm 1 \cdot 3$ ). They were also isolated from the spleens of $12 / 14$ mice infected 6 to 10 days before mating (geometric mean titre: $4.5 \pm 0 \cdot 8$ ), and from those of $7 / 15$ mice infected 11 to 15 days before mating (geometric mean titre: $4 \cdot 7 \pm 0 \cdot 8$ ). Mycoplasmas were not isolated from maternal blood specimens nor from any of the fetuses.

\section{Mice infected after mating}

Occurrence of abnormal pregnancies. The occurrence of abnormal pregnancies (one or more fetal deaths) in mice infected at different times after mating is shown in Table 2. In particular, pregnancies in which there were fetal deaths occurred significantly more frequently $(P=0.02)$ in mice that were infected 9 days after mating than they did in uninfected mice.

Arthritis in pregnant mice. There was no obvious association of abnormal pregnancy with the occurrence of arthritis. For example, in the group of mice infected 9 days after mating, abnormal pregnancies were seen in all four mice 


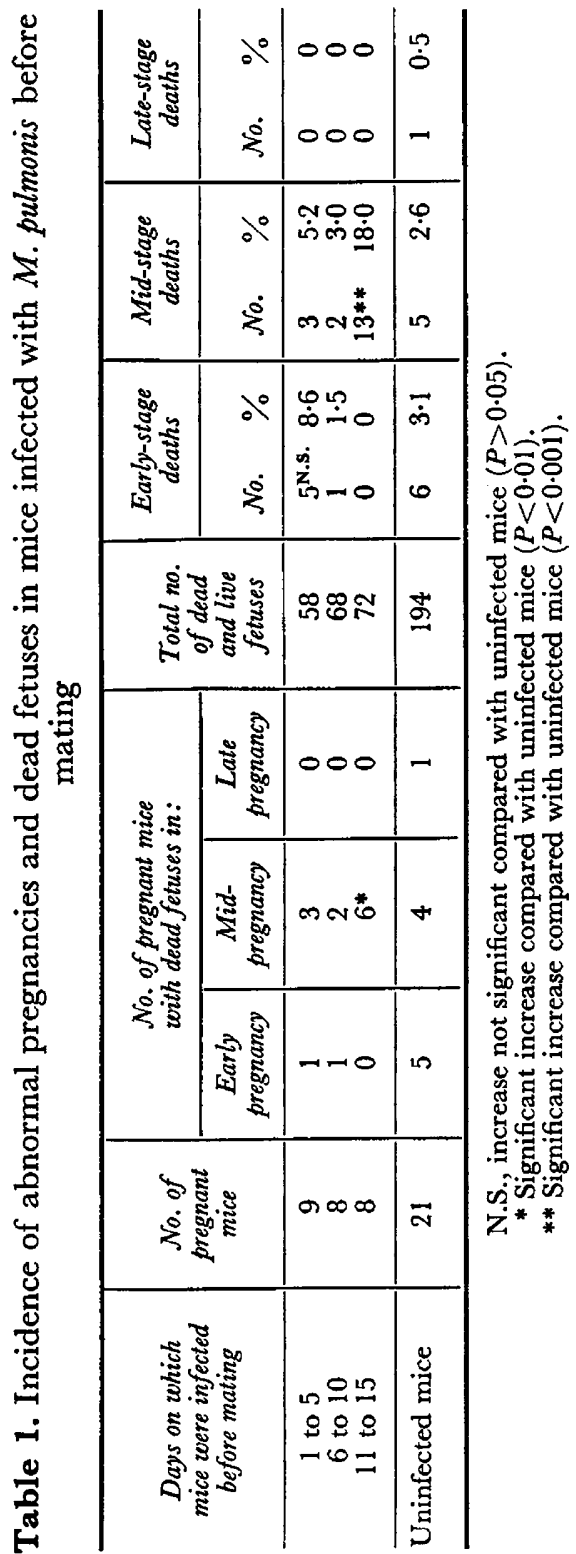




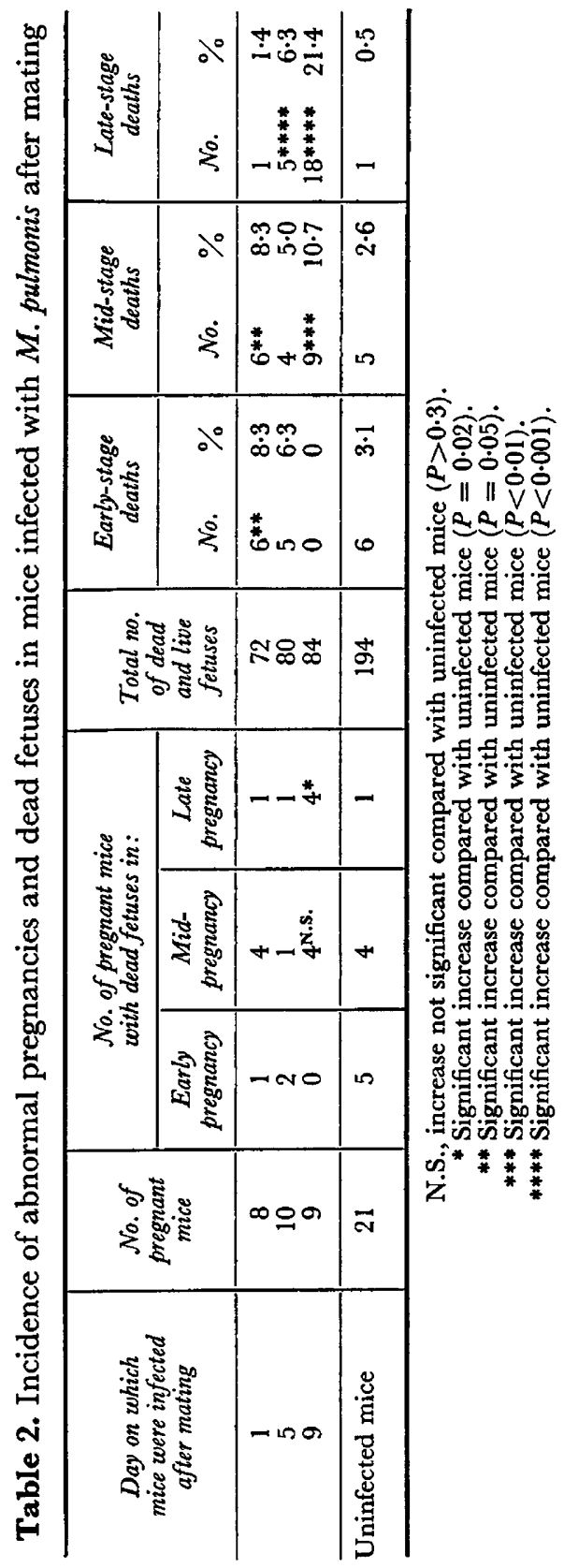


that developed arthritis but also in three of five mice that did not develop the disease.

Occurrence of abnormal fetuses. The incidence of fetal death in mice mated and infected 1,5 and 9 days later is shown in Table 2. Although there appeared to be an increase in the number of early- and mid-stage fetal deaths in mice infected 1 day after mating, a more obvious effect was seen in mice infected 5 days after mating. Here there was a clearly significant increase $(P<0.001)$ in the number of late stage fetal deaths. Furthermore, when mice were infected 9 days after mating, there was a significant increase in both mid-stage $(P<0.01)$ and latestage $(P<0.001)$ fetal deaths.

Table 3. Isolation of $M$. pulmonis from fetuses of infected mice

\begin{tabular}{|c|c|c|c|c|c|c|c|c|}
\hline \multirow{2}{*}{$\begin{array}{l}\text { Day on which mice } \\
\text { were infected } \\
\text { after mating }\end{array}$} & \multicolumn{2}{|c|}{ Early-stage deaths } & \multicolumn{2}{|c|}{ Mid-stage deaths } & \multicolumn{2}{|c|}{ Late-stage deaths } & \multicolumn{2}{|c|}{ Live fetuses } \\
\hline & $\underset{\text { positive }}{\text { No. }}$ & $\begin{array}{l}\text { Mean } \\
\text { titre }^{*}\end{array}$ & $\begin{array}{c}\text { No. } \\
\text { positive }\end{array}$ & $\begin{array}{l}\text { Mean } \\
\text { titre }\end{array}$ & $\begin{array}{c}\text { No. } \\
\text { positive }\end{array}$ & $\begin{array}{c}\text { Mean } \\
\text { titre }\end{array}$ & $\underset{\text { positive }}{\text { No. }}$ & $\begin{array}{c}\text { Mean } \\
\text { titre }\end{array}$ \\
\hline $\begin{array}{l}1 \\
5 \\
9\end{array}$ & $\begin{array}{l}6 / 6 \\
5 / 5\end{array}$ & $\begin{array}{l}>7 \cdot 0 \\
>7 \cdot 0\end{array}$ & $\begin{array}{l}4 / 6 \\
4 / 4 \\
9 / 9\end{array}$ & $\begin{array}{l}>7 \cdot 0 \\
>7 \cdot 0 \\
>7 \cdot 0\end{array}$ & $\begin{array}{c}1 / 1 \\
5 / 5 \\
12 / 12\end{array}$ & $\begin{array}{l}4 \cdot 0 \\
5 \cdot 5 \\
5 \cdot 3\end{array}$ & $\begin{array}{l}14 / 25 \\
24 / 25 \\
16 / 16\end{array}$ & $\begin{array}{l}5 \cdot 0 \\
5 \cdot 6 \\
5 \cdot 3\end{array}$ \\
\hline
\end{tabular}

* Expressed as $\log _{10}$ colour changing units $/ \mathrm{ml}$.

Weights of living fetuses. The mean weights of fetuses removed from mice infected 1,5 and 9 days after mating were $1.14 \pm 0.16 \mathrm{~g}, 1.07 \pm 0.17 \mathrm{~g}$ and $1.07 \pm$ $0.20 \mathrm{~g}$, respectively. As shown in Table 3, mycoplasmas were not isolated from all fetuses of mice infected 1 day after mating. There was no apparent difference, however, between the weights of fetuses from which mycoplasmas were isolated and the weights of those from which they could not be isolated. The mean fetal weights in each group were $1.15 \mathrm{~g}$ and $1.13 \mathrm{~g}$, respectively.

Isolation of mycoplasmas. Mycoplasmas were isolated from the spleens of each of the ten mice that were infected 1,5 and 9 days after mating. The mean mycoplasma titre for the spleens in each of these groups was $4 \cdot 3 \pm 0.9,6 \cdot 0 \pm 0 \cdot 7$ and $5 \cdot 7 \pm 0 \cdot 8$, respectively. Mycoplasmas were not recovered from maternal blood specimens but they were isolated from the fetal homogenates. Large numbers of organisms were isolated from fetuses that died early in development and from those that died in the middle stage (Table 3). By contrast, fewer organisms were isolated from homogenates of fetuses that died at a late stage of gestation and they were found in about the same numbers in living fetuses.

\section{DISCUSSION}

The results of these experiments clearly show that $M$. pulmonis causes fetal wastage in mice. The most striking features were the marked increase in the number of fetal deaths which occurred during mid-pregnancy in mice infected about 2 weeks before mating, and the increase in the number of mid- and latestage deaths in mice infected 5 or 9 days after mating. Thus, the timing of maternal infection seems to influence the extent to which the fetus is affected. 
Whether a particular organism causes fetal death because it infects and damages the fetus, involves the placenta or adversely affects maternal health may be difficult to determine. Although antigens associated with the Sendai virus have apparently been demonstrated by immunofluorescence in mouse embryos before the stage of implantation (Tuffrey, Zisman \& Barnes, 1972), Coid \& Wardman (1971) were unable to detect Sendai virus in the conceptuses of infected rats by culture methods and concluded that fetal loss was probably an indirect effect of maternal upset. Recent work by Lansdown \& Coid (1974) indicated that the poor health of pregnant mice infected with coxsackie B3 virus, in which pancreatitis, hepatic changes and protein deficiency were seen, underlay abnormal fetal development. In our experiments, the results of attempts to isolate $M$. pulmonis again suggest that maternal infection is the most important factor in fetal loss. Mycoplasmas were not isolated from any of the fetuses in the group of mice infected before mating. These mice quite rapidly eliminated mycoplasmas because the spleens of only half of them examined 30 to 34 days after infection contained the organisms. Other experiments (D. Taylor-Robinson, unpublished work) have revealed that $M$. pulmonis may be cleared from the blood within 6 days of intravenous inoculation so it seems that circulating organisms were absent or too few in number to infect the placentae of mice mated even a few days after intravenous inoculation. If placental infection did occur, the organisms did not pass through to the developing fetus. On the other hand, mycoplasmas reached and infected the joints of a proportion of the adult mice and it seems likely that poor maternal health, to which arthritis possibly contributed, was a factor in the increased incidence of abnormal pregnancies in this group.

In distinct contrast, mycoplasmas that were inoculated during pregnancy gained access to the fetuses since nearly all the fetal homogenates contained organisms. It is possible that they were directly responsible for some of the early- and mid-stage fetal deaths from which large numbers of mycoplasmas were isolated, although they were not isolated from all the mid-stage deaths. The numbers of organisms isolated from late-stage deaths were no greater than those isolated from living fetuses. The finding of mycoplasmas in the latter, which was not due to maternal blood contamination, suggests that late-stage fetal deaths were probably due to maternal infection and upset rather than to the fetal infection per se. Our conclusion that fetal infection does not seem to be the primary cause of fetal death is worth noting in the light of the human situation. Here, mycoplasmas have been isolated more frequently from abortions than from normal births, but the dilemma is that they may have gained entry to the fetus after death and may not be a cause of it, as Caspi et al. (1972) have pointed out.

Mycoplasmas have been isolated from the blood of women after parturition (Sompolinsky, Solomon, Leiba, Caspi, Lewinsohn \& Almog, 1971; Solomon, Caspi, Bukovsky \& Sompolinsky, 1973) but there are few reports of their presence in maternal blood before or during pregnancy, possibly because they have rarely been sought at these times. Despite this lack of information, fetal infection from the genital tract of the mother would seem far more likely than transplacental infection from the maternal blood stream. In retrospect, 
therefore, intravenous infection of mice, although clearly indicating that mycoplasmas can cause fetal wastage, is perhaps artificial and not necessarily analogous to the human situation. To throw further light on the latter, we have now established a chronic mycoplasma infection of the lower genital tract in mice to determine whether this adversely influences the course of pregnancy.

\section{ACKNOWLEDGMENTS}

We are grateful to Mrs M. F. Osborn and Mr G. F. Heath for technical assistance. Miss G. Rassner was a visiting worker from the Institute of Medical Microbiology, University of Lund, Sweden.

\section{REFERENCES}

Barden, J. A. \& Tully, J. G. (1969) Experimental arthritis in mice with Mycoplasma pulmonis. F. Bact. $100,5-10$.

CAspi, E., Solomon, F. \& Sompolinsky, D. (1972) Early abortion and Mycoplasma infection. Israel F. med. Sci. 8, 122-127.

CoId, C. R. \& Wardman, G. (1971) The effect of para-influenza type 1 (Sendai) virus infection on early pregnancy in the rat. 7 . Reprod. Fert. 24, 39-43.

Cole, B. C., Ward, J. R. \& Golightly-Rowland, L. (1973) Factors influencing the susceptibility of mice to Mycoplasma arthritidis. Infect. Immun. 7, 218-225.

CorTew, G. S. (1970) Diseases of sheep and goats caused by mycoplasmas. In The Rôle of Mycoplasmas and L Forms of Bacteria in Disease, pp. 198-211. Ed. J. T. Sharp. Thomas, Illinois.

Harwick, H. J., Purcell, R. H., Iuppa, J. B. \& Fekety, F. R., JR (1970) Mycoplasma hominis and abortion. $\mathcal{F}$. infect. Dis. 121, 260-268.

Jones, D. M. (1967) Mycoplasma hominis in abortion. Br. med. F. i, 338-340.

Kundsin, R. B., Driscoll, S. G. \& Ming, P. L. (1967) Strain of mycoplasma associated with human reproductive failure. Science, $\mathcal{N} . Y .157,1573-1574$.

Lansdown, A. B. G. \& Cord, C. R. (1974) Pathological changes in pregnant mice infected with coxsackie B3 virus as a possible cause of retarded foetal development. Br. F. exp. Path. 55, 101-109.

McLaren, A. \& Michie, D. (1959) Superpregnancy in the mouse. 1. Implantation and foetal mortality after induced superovulation in females of various ages. F. exp. Biol. 36, 281-300.

MANGheE, R. J. \& TAYLOR-RoBinson, D. (1968) Haemadsorption and haemagglutination by mycoplasmas. F. gen. Microbiol. 50, 465-478.

Romano, N., Garollo, F. \& Romano, F. (1968) Mycoplasmas in aborted and malformed foetuses. Riv. Ist. sieroter. ital. 43, 217-224.

Romano, N., Romano, F. \& Carollo, F. (1971) T-strains of mycoplasma in bronchopneumonic lungs of an aborted foetus. New Engl. 7. Med. 285, 950-952.

Solomon, F., Gaspi, E., Bukovsky, I. \& Sompolinsky, D. (1973) Infections associated with genital Mycoplasma. Am. 7. Obstet. Gynec. 116, 785-792.

Sompolinsky, D., Solomon, F., Leiba, H., Caspi, E., Lewinsohn, G. \& Almog, G. (1971) Puerperal sepsis due to T-strain Mycoplasma. Israel 7. med. Sci. 7, 745-748.

TAylor-Robinson, D. \& FurR, P. M. (1973) The distribution of T-mycoplasmas within and among various animal species. Ann. N.Y. Acad. Sci. 225, 108-117.

Taylor-Robinson, D. \& Purceld, R. H. (1966) Mycoplasmas of the human urogenital tract and oropharynx and their possible role in disease: a review with some recent observations. Proc. $R$. Soc. Med. 59, 1112-1116.

Thomas, L. (1970) The toxic properties of M. neurolyticum and M. gallisepticum. In The Rôle of Mycoplasmas and L Forms of Bacteria in Disease, pp. 104-109. Ed. J. T. Sharp. Thomas, Illinois.

TUffrey, M., Zisman, B. \& Barnes, R. D. (1972) Sendai (Parainfluenza 1) infection of mouse eggs. Br. J. exp. Path. 53, 638-640. 